\title{
Intercultural Communication in the Life and Mission of Arnold Janssen
}

\author{
Kasmir Nema ${ }^{a, 1}$ \\ University of St. Tomas (UST), Manila, Philippines ${ }^{a}$ \\ kasmirnema@gmail.com ${ }^{1}$
}

\section{Keywords:}

Intercultural

Communication,

Arnold Janssen,

Mission,

Dialogue.

\begin{abstract}
This study investigates the intercultural communication dimension of the life and mission of Arnold Janssen, the founder of the Divine Word Missionaries (SVD). This qualitative study involves a textual analysis on the relevant data and verbal descriptions about Janssen's life and mission. The results of the study show that the seed of Janssen's intercultural communication was primarily rooted in his parents. Being born in a family that was enveloped by a culture of prayer and a culture of peace, Janssen cultivated an intercultural sensitivity. This seed sprouted in his personality and spirituality. It revealed that Janssen was an intercultural-and-receptive person, interested in ethnic groups, cultures, beliefs and nationalities which were different from his own. Such interests were founded by a venturesome spirit which allowed him to welcome the unfamiliarity of the other and to value such differences. The researcher finds that Janssen's intercultural communication was contained in his practice of mission as dialogue. Through the lenses of mission, Janssen's dialogue competence enabled him to bridge differing views about mission and encourage missionaries to do the same.
\end{abstract}

\section{INTRODUCTION}

The study of intercultural communication is a fairly new academic initiative. However, the emergence of intercultural communication is inextricably intertwined with the history of humankind. The notion of intercultural communication combines two elements: the prefix inter suggesting between or among; and cultural. The purpose of intercultural communication means "communicative interactions between at least two people, each from different identifiable cultures." ${ }^{1}$

There have been many definitions of intercultural communication. Milton Bennett defines intercultural communication as "communication between people

William W. Neher and Paul J. Sandin, Communicating Ethically; Character, Duties, Consequences and Relationship (New York and London: Routledge, Taylor \& Francis Group, 2017), 158. 
of different cultures." ${ }^{2}$ The coverage of the field includes all ways, means and methods of such communication.

Furthermore, Edward T. Hall, in his basic book, The Silent Language, (1959), provides a concept of intercultural communication. Hall's emphasis is not only on the interpersonal communication which includes non-verbal communication but also is on the micro level dynamics. ${ }^{3}$ Hall's conceptualization reveals the ways in which human communication is affected by space and time. ${ }^{4}$ These definitions underline the common aspect of intercultural communication as an ongoing process of exchange of thoughts and meaning, between people of differing cultures. ${ }^{5}$

For the purposes of this work, the discussion of intercultural communication will focus on mission. Intercultural communication is closely associated with mission. The overflowing of the Spirit on the day of Pentecost and the birth of the Church, can be considered as an intercultural happening in the life of early Church community. It is derived naturally from the Trinitarian communion of love. That is, the Father, the Son and the Holy Spirit are unified in the circumference of divine communication. The quintessence of God, as pointed out by Martini, in fact, is "communion and communication." ${ }^{6}$ With the power of the Holy Spirit, the disciples were enabled to communicate with people

\footnotetext{
Bennett J. Milton, J, "Intercultural Communication: A Current Perspective," in Basic Concepts of Intercultural Communication: Selected Readings, ed. Milton J. Bennett (Yarmouth, ME: Intercultural Press, 1998), 2.

3 Edward T. Hall, The Silent Language (Garden City, New York: Doubleday \& Company, Inc., 1959), 62.

$4 \quad$ Adrian Holiday, John Kullman and Martin Hyde, Intercultural Communication. An Advanced Resource Book for Students (London and New York: Routledge, 2017), 75.

Franz-Josef Eilers, Communicating Between Cultures. An Introduction to Intercultural Communication. Fourth Updated Edition (Manila: Logos (Divine Word) Publications, 2012), 59.

6 Carlo Maria Martini, Communicating Christ to the World (Diliman: Claretian Publications, 1994), 21.
}

of various nations. Eilers notes that the Pentecost event is an "impressive example of intercultural communication" because it was "the communication of God's coming to people of all cultures of that time - in one language and one occasion."

Intercultural communication, however, brings its own challenges such as how people deal with cultural differences as well as different perspectives in community life. One of the most overriding questions in intercultural communication includes: how do people understand one another when they do not share a common cultural experience? The need for intercultural communication, for various reasons and aims, is indisputable, because "conflicts frequently arise due to tensions stemming from different cultural perceptions." ${ }^{8}$ How Arnold Janssen managed conflicts constructively and, consequently, achieved harmonious interaction are principal questions raised by intercultural communication scholars as will be addressed in this research.

Arnold Janssen was born on November 5, 1837 in Goch, a small town on the crossroads of the border between Germany and The Netherlands. His parents were Gerhard and Anna Katharina Janssen. He is the founder of three international mission congregations namely, the Divine Word Missionaries (SVD), ${ }^{9}$ Missionary Sisters of Servants of the Holy Spirit $(\mathrm{SSpS}),{ }^{10}$ and

\footnotetext{
Franz-Josef Eilers, Communicating in Ministry and Mission: An Introduction to Pastoral and Evangelizing communication, 4th Updated Edition (Manila: Logos (Divine Word) Publications, Inc, 2018), 31.

8 Xiaodong Dai and Gup-Ming Chen (eds). Introduction in Conflict Management and Intercultural Communication, the Art of Intercultural Harmony (London and New York: Routledge Taylor \& Francis Group, 2017), 1.

$9 \quad$ SVD stands for Societas Verbi Divini which means Divine Word Missionaries (1875), first of the three congregations found by Arnold Janssen. Their members are priests and brothers who are committed to living a consecrated life in response to a call from God.

10 Arnold Janssen together with Mother Maria Helena Stollenwerk,
} 
Servants of the Holy Spirit of Perpetual Adoration (SSpSAP). ${ }^{11}$

Tracing Janssen's journey in founding SVD is a comprehensive adventure. It involves his countless interactions with various parties. Inevitably, a multitude of issues and problems arose in the process. He encountered cultural differences as well as religious turbulence with the emergence of the "Kulturkampf" in Germany which resulted in the decline of religious practices in Germany. Janssen, who was raised in a very devoted Catholic family, was startled to witness a shift in the religious attitude of the people. This research tries to investigate the intercultural communication dimension in the life and mission of Arnold Janssen as the founder of the Divine Word Missionaries (SVD). This research commences by providing a general concept of intercultural communication in order to analyze the intercultural dimension of Janssen's life.

\section{GENERAL UNDERSTANDING OF INTERCULTURAL COMMUNICATION AND ITS DEVELOPMENT}

The definition of intercultural communication normally begins with the definition of two words: culture and communication. The first word, culture, has its origin in the Latin word cultura. It is a derivative of the verb colere which means "to nurse, to cultivate, to care for." ${ }^{12}$ The term culture holds various meanings throughout various disciplines according to its contextual setting and need. ${ }^{13}$

and Mother Josepha, Hendrina Stenmanns, (1889) lays the foundation of the Congregation of the Missionary Sisters Servants of the Holy Spirit (SSpS), as a religious-missionary community dedicated to the life-giving Spirit.

11 Third Congregation founded by St. Arnold Janssen (1891) with Mother Mary Michael, Adolfine Tönnies, as Co-foundress.

12 Franz-Josef Eilers, Communicating in Ministry and Mission: An Introduction to Pastoral and Evangelizing communication, 19.

13 Franz-Josef Eilers, Communicating in Ministry and Mission: An
In line with this root meaning, communication scholar Wen Shu Lee identifies different common uses of the term culture. ${ }^{14}$ According to Lee, culture is a unique human endeavor which is characterized by shared languages, beliefs and values, and not the biologically inherited characteristics. $^{15}$ Scholars from various disciplines agree that culture should contain "a set of norms, standards, association notions and beliefs for coping with various demands of life." 16

The second word, communication, is etymologically related to "communion" and "community", both of which originate from the Latin word communis meaning "to make common", "to have something in common, or to share." 17 The things in common in a community could imply information, knowledge, or meaning. This notion of having something in common implies also "mixing or exchanging" cultural meanings among the members of the community which takes place in their processes of interaction. This meaning serves to define communication as the "practice of creating and exchanging meanings or symbolic resources." 18

As a symbolic process, communication means something which can be shared and negotiated. In order to receive meaning in this process, the contact is established and signs are exchanged. ${ }^{19}$ The contact is established

Introduction to Pastoral and Evangelizing communication, 20.

14 M. J. Collier, R. Hedge, W.S. Lee, T. Nakayama, and G. Yep, "Dialogue on the Edges: Ferment in Communication and Culture," in: Communication about Culture, ed. M. J. Collier (Thousand Oaks, Ca: Sage, 2002), 229.

15 M. J. Collier, R. Hedge, W.S. Lee, T. Nakayama, and G. Yep, "Dialogue on the Edges: Ferment in Communication and Culture," in: Communication about Culture, 229

16 Igor E. Klyukanov, Principles of Intercultural Communication (New York: Pearson, 2005), 9.

17 Franz-Josef Eilers, Communicating in Ministry and Mission: An Introduction to Pastoral and Evangelizing communication, 19.

18 Igor E. Klyukanov, Principles of Intercultural Communication, 10.

19 Franz-Josef Eilers, Communicating in Ministry and Mission: An 
by the participants of communication. The signs can be both verbal words and language, as well as non-verbal expressions.

Culture and communication are components of intercultural communication, and the two cannot be separated. They are interrelated. Culture is influenced by communication, and reciprocally, communication is influenced by culture. ${ }^{20}$ These root meanings of culture and communication lead to a definition of intercultural communication as the interaction of people who come from dissimilar cultural backgrounds. Within these interactions, the "process of the exchange of thoughts and meaning between people of differing cultures," occurs. ${ }^{21}$

Moreover, the concern of intercultural communication involves a participatory principle. In this approach, "one shares and becomes one with the other in the attempt to mutually understand and coorporate." 22 Since the sequence of communication is understood as a process of exchange between people of different cultures, it examines how the specific cultural differences affect their interactions.

The development of the field as an academic enterprise began with the publication of The Silent Language by Edward T. Hall in 1959. Hall is considered as the first person to use the term Intercultural Communication even though the term of intercultural has been used prior to the publication of his book. ${ }^{23}$ Hall conducted

Introduction to Pastoral and Evangelizing communication, 24.

20 Igor E. Klyukanov, Principles of Intercultural Communication, 10.

21 Gerhard Maletzke, "Intercultural and International Communication," in International and Intercultural Communication, ed. Fischer, H.D./ Merill, John C, Second Edition (New York...), 409-419.

22 Franz-Josef Eilers, Intercultural Communication in a Digital World in Intercultural Mission, ed. Lazar T. Stanislaus and Martin Ueffing, vol. 2 (Delhi: ISPCK, 2015), 406.

23 James W. Neuliep, Intercultural Communication: A Contextual an intercultural training for the Foreign Service Institute (FSI) of American officials who were sent overseas in diplomatic foreign service.

Through the teaching experience, Hall discovered that "the traditional ways of teaching about micro-level culture, from an anthropological perspective, were not effective in training FSI personnel how to interact with persons from different cultures." ${ }^{4}$ This experience led Hall and others to think about how to teach about culture and develop a new curriculum which became known as intercultural communication. The concern of this new curriculum was no longer how members of a particular group interact within their culture, but shifted to the interactions of people across different cultures.

Recent approaches of the field emphasize the role of context in studying intercultural communication and its interpretation of communication. Such context is determined by the environment, shaped by the social, political and historical realities, that surrounds every person who is involved in the communication process. For this reason, the present research sets the life and mission of Arnold Janssen as the context for its analysis on Janssen's intercultural communication dimension.

\section{INTERCULTURAL COMMUNICATION AND MISSION}

Intercultural communication can be considered as a paradigm of the Church's mission, rooted from and leading to "the

Approach, Seventh Edition (Thousand Oaks: Sage, 2018), 19 See also Edward T. Hall, The Silent Language, 15.

24 James W. Neuliep, Intercultural Communication: A Contextual Approach, 15 .. 
mission of the Triune God (Missio Dei)."25 This understanding of mission is derived from the Second Vatican Council Decree on the Church's Missionary Activity, Ad Gentes (AG), which states: "The pilgrim Church is a missionary by its very nature. Firstly, for it is from the mission of the Son and the mission of the Holy Spirit that it takes its origin, in accordance with the decree of God the Father." (AG 2). God, who is the primary source of mission, entrusted his mission to his Son, Jesus Christ, and through the Holy Spirit empowered the disciples to receive that same mission and proclaim it to the Church which was inaugurated at the day of Pentecost (Acts 2:1-13).

Secondly, the Church is called to give witness to the world in its soteriological mission. ${ }^{26}$ In line with this, Gaudium et Spes (GS), emphasizes that the mission of God is not restricted to the Church only, but it must look for God's activity in the world and all of creation in the "signs of the times" and in a language intelligible to each generation (GS 4). This foundation urges the Church, in her mission, to be present to all aspects of creation, including other Christians Churches, to people of all cultures and all religions (GS 22).

This understanding of Missio Dei highlights the Church's mission in an intercultural society. It is in accordance with Arnold Janssen's understanding of mission in the context of his time, which could be modelled as follows:

\section{a).Mission is dialogue}

It is understood as "the normal and necessary manner of very form of Christian mission, as well as of every aspect of it,

\footnotetext{
25 Roger Schroeder, Interculturality as a Paradigm of Mission in Intercultural Living, ed. Lazar T. Stanislaus and Martin Ueffing, vol. 1 (Delhi: ISPCK, 2017), 157.

26 Roger Schroeder, Interculturality as a Paradigm of Mission in Intercultural Living, 158.
}

whether one speaks of simple presence and witness, service or direct proclamation."27 It underscores the spiritual character of dialogue, "in which both sides listen and talk, give and take, learn and share." ${ }^{28}$ These characteristics of dialogue allow those engaged to listen to and learn from each other's language and culture, ${ }^{29}$ and even be challenged by others. Only within this understanding, the concept of mission as dialogue would have its full impact. The fruits of a true intercultural mission, therefore, will be plentiful when it is performed on the ground of mutual openness, listening, learning, giving, and sharing.

From its beginning, Arnold Janssen's understanding of mission as dialogue was ingrained in the name of the congregation, the Divine Word, or Logos. When analyzing this name, Eilers, echoing Joseph Ratzinger's preposition on God's way of communication, claims that "the Society of Divine Word (Logos) should be a society of dialogue, the society of Divine Dia-Logos", which becomes the basis for dialogue and prophetic dialogue in mission. ${ }^{30}$

Furthermore, Arnold Janssen's understanding of mission as dialogue can be found in his writings in Little Messenger. ${ }^{31}$

$27 \quad$ Secretariat for Non-Christians, "The Attitude of the Church Towards Followers of Other Religions: Reflections and Orientations on Dialogue and Mission," Bulletin. Secretariatus pro non Christianis 56:13, 1984/2, Paragraph 29.

28 Franz Gmainer-Pranzl, "From "Inculturation" to "Interculturation" An Essay in Mission Theology" in Intercultural Mission, ed. Lazar T. Stanislaus and Martin Ueffing, vol. 2 (Delhi: ISPCK, 2017), 143.

29 Franz-Josef Eilers, Communicating in Ministry and Mission: An Introduction to Pastoral and Evangelizing communication, 188.

30 Franz-Josef Eilers, Communicating in Ministry and Mission: An Introduction to Pastoral and Evangelizing communication, 56.

31 Little Messenger of the Sacred Heart was a magazine founded by Arnold Janssen and the first issue was published in January 1874 , a year before he found SVD. The publication of the magazine aimed to inform people about the Catholic Missions at home and abroad in a readable and interesting manner. The magazine however shifted later to mainly deal with the 'missions abroad' or 'pagan missions', the normal terms used in those days. Arnold Janssen's understanding of mission was 
In Ommerborn's words, for Arnold Janssen, "mission was not one-way streetfrom Europe to the mission countries. Missionary work overseas has or is supposed to have an effect on the people in the home or mission-sending countries, too." ${ }^{32}$ It is apparent, then, that dialogue is a prerequisite for the communication to be effective between the missionaries and the people to whom the missionary is sent, and between the people in the mission and those in the mission-sending countries. His words illustrate this idea of mission in the following way:

It is our sincere wish that many readers may study the map and help each other to understand it. Every effort expended to this end will be very worthwhile. Possibly the first map will still be difficult to read, the second will already be easier and the third easier still. In the end, when you come across a really big map, you will be happy to see how much you already know about the mission countries. ${ }^{33}$

With this dialogic concept of mission, Arnold Janssen wants to create bonds between the people in the mission-sending countries and the people in the mission, who were referred to as the non-Christian world, so that they may no longer be strangers and may be able to see the world from other perspectives.

\section{b). Mission is praxis}

This insight is the implementation or concretization of the Second Vatican Council's understanding of mission as

mainly expressed through this magazine. In this perspective, the magazine was employed as a means for dialogue between Arnold Janssen and his readers. That was the way how Arnold Janssen reached out to the people (readers).

32 Jürgen Ommerborn, "Arnold Janssen's Understanding of Mission," Verbum SVD 49, no. 3 (2008): 261.

33 Jürgen Ommerborn, "Arnold Janssen's Understanding of Mission," Verbum SVD 49, no. 3 (2008): 261. presence through dialogue (AG 5). Being missionary by nature means that Christians are called to witness their faith without having the intention to impose it onto others.

Mission as praxis sees God's revelation in the whole history of human beings, namely, in the events of everyday life, in social, economic and cultural structures, and in people's struggle with poverty, injustice, and marginalization. Within such reality, the fundamental task of mission is to bring God's healing power of reconciliation and liberation. $^{34}$

\section{c). Mission is kenosis}

This term adopts the metaphor used by St. Paul in his letters to the Philippians (Phil 2:7). Kenosis is a metaphor which "shows the self-emptying of Jesus Christ that the way to life begins with the risk of losing oneself in unfamiliar spaces. It is a willingness to become "poor' for the sake of others." 35 This spirituality calls a new way of life that leads to emptying oneself from power, security and wealth for the sake of God's universal mission. It is in line with the perspective of an intercultural mission whereby values of mutual respect and dialogue are held over any superiority and inferiority about one's culture or other cultures that needs to be practiced by "exposing oneself to unknown cultures." 36

Mission as kenosis means a radical call to practice kenosis in a peripheral society. In the frame of an intercultural mission, missionaries are called not only to learn new cultures, languages and immersing oneself into each mission circumstance but

\footnotetext{
34 Jürgen Ommerborn, "Arnold Janssen's Understanding of Mission," Verbum SVD 49, no. 3 (2008), 75.

35 Franz Gmainer-Pranzl, "From "Inculturation" to "Interculturation" An Essay in Mission Theology" in Intercultural Mission, 145.

36 Franz Gmainer-Pranzl, "From "Inculturation" to "Interculturation" An Essay in Mission Theology" in Intercultural Mission, 145
} 
also to let go of their former convictions in order to regain "kenotic intercultural communication." 37 This new experience is an experience of emptiness which is part of the spirituality of missionaries in intercultural missions. In intercultural mission, the goal is to bear witness to God's Word in the world. Kenosis, or self-emptying, is a significant part of such a goal as it demands radical openness and humility to firstly listen to the Word that speaks through the life-giving elements of various cultures, and the willingness to enter into the process of transformation.

This concept of mission as kenosis is particularly in line with Arnold Janssen's view of mission. Through the "Apostleship of Prayer" he states that mission means adopting the mind, the intentions, the goals of Jesus as one's own, which implies "praying, working and suffering for the glory of God and the salvation of souls." 38

\section{THE LIFE OF ARNOLD JANSSEN IN INTERCULTURAL PERSPECTIVE}

It is important to note here that the time period being studied is the period of Janssen's lifetime and particularly the time during which he founded the mission house in Germany in 1975. This following part of the essay unpacks Janssen's cultural and socioreligious origins. His life was conditioned by the society around his time between the late $19^{\text {th }}$ and beginning $20^{\text {th }}$ century.

\section{Family and Cultural Roots}

The intersection between Janssen's family circumstances and culture can be seen in three different perspectives, and

\footnotetext{
Franz Gmainer-Pranzl, "From "Inculturation" to "Interculturation" An Essay in Mission Theology" in Intercultural Mission, 145.

38 Jürgen Ommerborn, "Arnold Janssen's Understanding of Mission," 247.
}

similarly the intersection between Janssen's family circumstances and the aspects of intercultural communication. First, one's family reflects and passes down the surrounding culture. Family is "the place where culture is learned and develops their own cultures." ${ }^{9}$ This concept is in line with the understanding of culture being learned through observation, interaction and imitation, all of which can be acquired from and with one's family situation. ${ }^{40}$

In the case of Janssen's family roots, a 'culture of prayer' was inherited from his parents which gave roots to his personal life and mission, inspiring him to become a man of prayer. ${ }^{41}$ Gerhard Janssen, Arnold's father, loved to pray the rosary and always began his task with a prayerful phrase "all with the Lord God". ${ }^{42}$ From his father's prayer habit, Janssen inherited such deep and strong faith. Not only did Janssen describe his father as someone who was concerned about the faith, he described his father as a faithful Christian. The faithfulness of his father was shown through his regular participation in the Eucharist, twice in the morning and once again in the afternoon on Sundays. ${ }^{43}$ A similar attitude was shown by his mother, Anna Katharina. She had a great devotion and dedicated herself to the Holy Eucharist. ${ }^{44}$ Through both of his parents, not only did Janssen learn how to pray, but also

39 John R. Baldwin, "Intercultural Communication in Families," derived on March 26, 2019 (https://doi. org/10.1002/9781118783665.ieicc0046).

40 Louis J. Luzbetak, The Church and Cultures: An Applied Anthropology for the Religious Worker (Techny, Illinois: Divine Word Publications, 1970), 60-61.

41 Leonardo R. Estioko, Witness to the Word (Manila: Logos Publication, 2005), 28.

42 Josef Alt, Journey in Faith: The Missionary Life of Arnold Janssen (Rome: Apud Collegium Verbi Divini, 2002), 8.

$43 \quad$ Franz-Josef Eilers and Heinz Helf, Arnold Janssen, 1937-1909: A Pictorial Biography, 2nd Edition (Manila: Philippine Edition Divine Word Publication, 1987), 10.

$44 \quad$ Franziska Carolina Rehbein, Gripped by The Mystery, Arnold Janssen - Man of Prayer (Steyler Verlag: Arnold Janssen Spirituality Center (AJSC), 2004), 19. 
how to live faithfully. The culture of prayer characterized his life and mission, and gave a strong foundation to his personal prayer life. Rehbein describes Janssen's attitude to prayer as follows:

Right from his school days at Gaesdonck, he wrote prayers: for his family, then later as a young priest for the members of the Apostleship of Prayer, for the readers of his magazine, and for the members of the three Congregations he founded. It is tempting to ask whether his prayer life exhausted itself in oral prayers and remained mainly in that sphere. ${ }^{45}$

From his parents, Janssen also learned a 'culture of peace'. When Gerhard, Janssen's third brother, had a dispute with his mother and wife, he sought Janssen's advice. To resolve the issue, Janssen suggested that they should follow their father's example, that is, to keep silent and seek peace. He learned from their father that silence is "the quickest and the best way" to keep peace. ${ }^{46}$

Secondly, Janssen's parents represented two divergent cultures, namely, the Frauenstrasse culture of his father who originated in Goch, and the culture of Heust through his mother. In addition, Janssen's father, Gerhard Janssen, was engaged in business relations with people across the German borders. Furthermore, Arnold's father was engaged in an export-import business with people in the Dutch town of Nijmegen across the German borders. For similar business purposes, he travelled regularly to Geldern and Straelen. ${ }^{47}$ Such an environment was intercultural in nature and enabled Janssen's family to develop

\footnotetext{
Franziska Carolina Rehbein, Gripped by The Mystery, 119.

$46 \quad$ Franziska Carolina Rehbein, Gripped by The Mystery, 119.

47 Franziska Carolina Rehbein, Gripped by The Mystery, 119.
}

communication skills in order to keep business relations with people of other cultures. ${ }^{48}$ Hence, their household became somehow a fertile ground for intercultural communication approaches to flourish in their day-to-day interaction among their relatives and with their business partners.

The cultural realities in which Janssen lived can be uncovered through his communication with the other members of his family. In his writings, Janssen showed a close bond of relationship with his siblings. He put a significant effort in writing a short biography for each of his siblings as well as biographies for his parents. Those biographies were written for the occasion of the silver Jubilee of SVD in 1900. ${ }^{49}$ Maintaining an open communication within his family circle allowed him to express his needs, wishes, and concerns. An open and honest communication creates an atmosphere where family members feel free to express their differences, while expressing their love and admiration for one another. With this in mind, Janssen used letter writing as an important communication tool to communicate with his family. While studying at the Secondary School at Gaesdonck, for instance, he admonished his siblings to show good behavior and to love one another as their parents had shown them. ${ }^{50}$

In his letters, Janssen's approach to communication can be characterized into discussion and persuasion. Regarding the funeral of his mother, he did not take any decision before discussing it with his brothers and sisters. ${ }^{51}$ With regard to his brother Peter,

\footnotetext{
$48 \quad$ Franz-Josef Eilers and Heinz Helf, Arnold Janssen, 1937-1909: A Pictorial Biography, 12.

49 Josef Alt, Journey in Faith: The Missionary Life of Arnold Janssen, 3-7.

50 Josef Alt, Journey in Faith: The Missionary Life of Arnold Janssen, 13.

51 Josef Alt, Journey in Faith: The Missionary Life of Arnold Janssen, 4.
} 
Janssen persuaded their father to allow Peter to take further studies so that he could later manage a printing press. ${ }^{52}$ Although that idea was refused by their father, Janssen did not impose his idea on his father.

Janssen's family background shows at least three dimensions of intercultural communication. Firstly, the surrounding culture that was practiced in his family through his parents, which was built upon the culture of prayer and the culture of peace, cultivates intercultural sensitivity. Secondly, Janssen and his siblings inherited aspects of interculturality from his father who ran an 'international' business, and from both of their parents who were brought up with different cultures. Thirdly, Janssen's style of communication with his parents and siblings gives clear indications of discussion and persuasion, both of which are key characters of intercultural communication.

\section{Social, Political and Religious Contexts}

The rise of Kulturkampf marked a dark period in the history of the Catholic Church in $18^{\text {th }}$-century Europe. It was under the leadership of King Louis XIV in France when the influence of the Church's role in the public affair was lessened as the French king made a policy to delimit Rome's control over the national Church. ${ }^{53}$

In Germany in the year of Janssen's birth year, 1837, there was a 'Cologne incident' which led to the imprisonment of the Archbishop of Cologne, Clemens August Drostezu Vischering, on November $201837 .{ }^{54}$ This incident significantly changed the Church-state relation and signaled the beginning of a new chapter

\footnotetext{
52 Josef Alt, Journey in Faith: The Missionary Life of Arnold Janssen, 4-5.

53 Matthew Bunson, "German Catholics Under the Iron Fist: Bismarck and the Kulturkampf" derived on October 26, 2019 from https://www.catholicculture.org/culture/library/view. cfm?recnum $=8670$

54 Josef Alt, Journey in Faith: The Missionary Life of Arnold Janssen, xiii.
}

in the history of the Church in Germany. In 1848, the Church gained its liberty from state governance, and at the first Catholic Congress held at Mainz, German Catholics gained a new self-understanding.

The political turbulence reached its peak during the so-called Kulturkampf (German for "culture struggle") which took place from 1871 to $1887 . .^{55}$ The relation between the Church and the government was strained. With a series of anti-Catholic laws, some religiousowned schools were shut down. The laws also led to the expulsion of some priests and bishops to imprisonment and suspended the relations between Germany and the Vatican. ${ }^{56}$ Not only did this situation result in the nonsubstitution of clergy, leaving many of parishes without parish priests, but also the cessation of seminaries and severe cases of persecution towards religion. ${ }^{57}$

In spite of the Kulturkampf, Janssen grew up as a Catholic and struggled with the Church. Unlike many Catholics, Janssen saw such struggle as an invitation. Against all odds, Janssen decided to establish a mission seminary. Seeing the phenomenon under the perspective of interculturality, Kulturkampf offered a challenge to Janssen to strive for the development of faith and mission. He saw the Kulturkampf both a challenge and an invitation for Catholics to strengthen their faith. ${ }^{58}$ Because of Kulturkampf, it was impossible to establish a mission home within the soil of Germany. Janssen was triggered to discern God's call for him to expound the missionary endeavor beyond the given socio-political constraints. ${ }^{59}$

\footnotetext{
55 Josef Alt, Journey in Faith: The Missionary Life of Arnold Janssen, XIII.

56 Josef Alt, Journey in Faith: The Missionary Life of Arnold Janssen, XIII

57 Josef Alt, Journey in Faith: The Missionary Life of Arnold Janssen, XII- XIV.

58 Josef Alt, Journey in Faith: The Missionary Life of Arnold Janssen, XV.

59 Josef Alt, Journey in Faith: The Missionary Life of Arnold
} 
The fact of Kulturkampf also motivated him to contemplate on the universal mission of the Church as it brought him into the realm of intercultural encounters.

The universal mission of the Church blossomed in the $19^{\text {th }}$ century. The expansion of mission benefited from the European colonial expansion to Africa, Asia, and Oceania. ${ }^{60}$ Germany as a nation gained its colonial power only in 1884 . Even three years prior to this, Janssen had begun to send some of his missionaries to work in foreign countries. ${ }^{61}$

The culture of Kulturkampf and the challenges which came with this influenced Janssen's capacity to establish the Society of Divine Word. It brought to his consciousness a particular way of dealing with cultural differences, which complemented his attitude towards a pluralistic environment in his hometown, Goch. It was mainly Catholic but also a multi-religious town which accommodated four different religions and traditions including Catholicism, Jews, Protestantism of various nominations, and Mennonite. ${ }^{62}$

\section{INTERCULTURAL COMMUNICATION DIMENSION IN JANSSEN'S PERSONALITY}

This part of the essay discusses Janssen's legacies and resolutions through the lenses of intercultural communication. It identifies important areas of his personality and mission through which he cultivated an intercultural communication competence. The

Janssen, $\mathrm{XV}$.

60 Josef Alt, Journey in Faith: The Missionary Life of Arnold Janssen, XVI.

61 Josef Alt, Journey in Faith: The Missionary Life of Arnold Janssen, 177.

62 Josef Alt, Journey in Faith: The Missionary Life of Arnold Janssen, 8. intercultural communication competence, in this sense, means "a system of knowledge and skills enabling us to communicate successfully with people from other cultures." ${ }^{63}$ For intercultural communication to be effective, recent studies find that a proper inner disposition of the persons involved and a lived spirituality are essential as to support the communicative ability of the participants. ${ }^{64}$

In light of the above insight, researchers have identified that, intercultural receptivity, venturesome spirit and spirit of flexibility, ${ }^{65}$ are three necessary skills, among others, that enhance people's intercultural competence. These skills are reflected in Janssen's personality and substantiated Janssen's intercultural communication in his life and mission.

\section{Intercultural Receptivity}

Intercultural receptivity is an intercultural skill that is demonstrated by people who show interest in other people, especially with people who come from other cultures. ${ }^{66}$ Since the establishment of the mission house, Janssen was always interested in other ethnic groups, other cultures, beliefs and nationalities. In fact, soon after the inauguration of the mother house in Steyl, in 1875, he established a 'German-Austrian Mission House' in 1889. The creation of this boundary-crossing house hoped to accommodate a number of representatives of the congregation from Germany and

\footnotetext{
63 Igor E. Klyukanov, Principles of Intercultural Communication, 9.

$64 \quad$ Franz-Josef Eilers, Intercultural Communication in a Digital World in Intercultural Mission, ed. Lazar T. Stanislaus and Martin Ueffing, vol. 2 (Delhi: ISPCK, 2015), 406.

65 Divine Word Missionaries, "Intercultural Competence: The Intercultural cCmpetency scale--Skill Builder," (november 12, 2017). Retrieved July 25, 2019 from http://www.svdcuria.org/ public/formatio/, 1.

66 Divine Word Missionaries, "Intercultural Competence: The Intercultural competency scale--Skill Builder," 1.
} 
Austria. In line with this boundary-crossing community, Janssen decided to establish a headquarter in Rome as to diminish nationalistic conflicts and tensions. ${ }^{67}$

Upon the request of professor Hengesch from Luxembourg, Janssen's receptive attitude towards other people of different cultures developed. He agreed with Hengesch and sent his missionaries to support German nationals who had migrated to Argentina. On September 22, 1889, Janssen commissioned two priests, Becher and Loecken, to realize this mission in Buenos Aires, Argentina. ${ }^{68}$ He insisted, however, that they would not only serve the Germans, but also care for the other groups of migrants such as Italians and French. ${ }^{69}$ Again showing his receptivity, he said, "you must follow the example of Good Shepherd and try to find all the lost sheep for the Kingdom of heaven" 70 as he urged the missionaries in Argentina to give higher priority to the salvation of the people rather than being concerned about the facilities that supported their ministry.

\section{Venturesome Spirit}

The venturesome spirit that is required in an intercultural communication parlance elucidates one's openness and inclination towards the customs and behaviors which are novel or different from one's own. ${ }^{71}$ Such spirit enables people to embrace unfamiliarity and differences. In this regard, two significant skills should be highlighted. Firstly, one's ability to cope with and adapt to

67 Josef Alt, Journey in Faith: The Missionary Life of Arnold Janssen, 916.

68 Josef Alt, Journey in Faith: The Missionary Life of Arnold Janssen, 552.

69 Fritz Bornemann, Arnold Janssen: Founder of Three Missionary Congregations, 1837-1909: A Biography (Manila: Arnoldus Press, 1975), 218.

70 Fritz Bornemann, Arnold Janssen: Founder of Three Missionary Congregations, 1837-1909: A Biography, 553.

71 Divine Word Missionaries, "Intercultural Competence: The Intercultural Competency Scale--Skill Builder", 14. different situations, and secondly, to initiate relationships with other people beyond familiar circumstances. ${ }^{72}$

How did Janssen develop a venturesome spirit in his life and mission? Janssen's venturesome spirit is reflected in his approach to establish the mission house in Steyl, Holland, beyond the familiar borders of his hometown. ${ }^{73}$ The impossibility of founding the mission house within the German soil, due to the phenomenon of Kulturkampf, encouraged him to cross the borders of Germany. Not only did he concede that he would enter new geographical and socio-cultural settings, he was willing to collaborate with foreign people whose cultures were dissimilar from his own culture. Janssen was willing to bear the weight of his decision, in spite of the skeptical remarks that he received about the initial condition of the mission house. ${ }^{74}$

Beyond any doubt, Janssen was assured that the mission house would not perish. ${ }^{75}$ His homily on the inauguration day of the mission house in Steyl inspired many as it revealed his venturesome spirit in the given situation. He said, "we hope that the house will attain its purpose. The simplicity of this beginning should not discourage us." 76

One year later, the mission house was burdened by internal conflicts among its members on top of its poverty and declining collaborators. The situation of the mission house was overshadowed by internal conflicts among its members. They were

\footnotetext{
72 Divine Word Missionaries, "Intercultural Competence: The Intercultural Competency Scale--Skill Builder", 14.

73 Josef Alt, Journey in Faith: The Missionary Life of Arnold Janssen, 69.

74 Josef Alt, Journey in Faith: The Missionary Life of Arnold Janssen, 82.

75 Josef Alt, Journey in Faith: The Missionary Life of Arnold Janssen, 93.

76 Josef Alt, Journey in Faith: The Missionary Life of Arnold Janssen, 80.
} 
troubled by the general goal of the mission house, but especially by Janssen's strict asceticism around how they should live as a community and his role as superior. ${ }^{77}$ This crisis did not deter Janssen from attaining his missionary project.

Janssen's venturesome spirit was even noticed by Bishop Vaughan after his visit to the mission house in its early beginnings in Steyl. He commented as follows:

Last year I passed through Holland on my way to Rome, and I heard that little missionary college had just been established on the border of Holland, of which a German priest was the head-and I spoke with him about its origin. I said, 'Well, you are a man of spirit, for while you Germans are being persecuted at home, you are establishing a college for foreign missions. ${ }^{78}$

Janssen's response to the bishop showed his inclination towards other people's circumstances and needs, where he said: "We have ministered to our own wants and we have forgotten those abroad who have no one to minister to them."

Janssen's venturesome spirit was also shown through his readiness to initiate relationships with bishops (i.e. Bishop Raimondi, Bishop Paredis, Bishop Brinkmann, Bishop Melchers, etc.), collaborators and benefactors. ${ }^{80}$ Although he did not know each of them personally, Janssen took the initiative to meet them and engaged them in the conversation. These encounters

\footnotetext{
77 Josef Alt, Journey in Faith: The Missionary Life of Arnold Janssen, 94.

78 Josef Alt, Journey in Faith: The Missionary Life of Arnold Janssen, 95.

79 Josef Alt, Journey in Faith: The Missionary Life of Arnold Janssen, 95.

80 Josef Alt, Journey in Faith: The Missionary Life of Arnold Janssen, 44-65.
}

are notably considered as significant building blocks in the establishment of the mission house. ${ }^{81}$

\section{Spirit of Flexibility}

Spirit of flexibility is an attitude of those who are open to a new culture and willing to learn about it. ${ }^{82}$ The possibility to be accepted by others, in an intercultural setting, is guaranteed for those who are flexible and willing to learn new customs and languages. Janssen's spirit of flexibility evolved throughout his life and mission. It enabled him to capture the positive implications amidst the negative influences caused by the Kulturkampf. Rather than being overshadowed by the adversity of the Kulturkampf, Janssen took it as another reality of cultural differences. ${ }^{83}$ The spirit of flexibility enabled him to seek new opportunities amidst such phenomenon.

Janssen's spirit of flexibility is also shown through his propensity for science. For him the scientific culture and progress do not obstruct the ways in which the Word of God would be proclaimed. He believed that science should never be the enemy of the mission of the Church. Mission and science should be synthesized, as they are complementary to each other, since science would offer a great opportunity and blessing for the promotion of the mission of the Church. ${ }^{84}$ In the spirit of flexibility, thus, Janssen insisted on the insertion of science subjects into the seminary curriculum for the Divine Word Missionaries. ${ }^{85}$

\footnotetext{
$81 \quad$ Fritz Bornemann, Arnold Janssen: Founder of Three Missionary Congregations, 1837-1909: A Biography, 45.

82 Divine Word Missionaries, "Intercultural Competence: The Intercultural Competency Scale--Skill Builder," 11.

83 Josef Alt, Journey in Faith: The Missionary Life of Arnold Janssen, XV.

84 Anthony Porunthur, "Arnold Janssen's Passion for Science," Verbum SVD 46, no. 3 (2005): 354.

85 See Philip Gibs, "Mission and Culture: The SVD Connection," in Mission and Culture: The Louis Luzbetak Lectures, ed. S. Bevans (Maryknoll, New York: Orbis Books, 2012), 292, quoted in Agcaracar, Interculturality, 91.
} 


\section{Spirituality}

Spirituality in this sense is not merely about "prayers and spiritual exercises. It is about the spirit that motivates someone, and forms the frame of his/her ideas, values and deeds." ${ }^{86}$ The Trinitarian devotion is at the center of Janssen's spirituality. Inherited from his parents, his spirituality is not limited to spiritual asceticism, but serves as his guidance and direction towards mission. ${ }^{87}$ The Trinitarian spirituality, hence, entirely imbued Janssen's life and became his main source of inspiration. ${ }^{88}$

Referring to Arnold Janssen, Sandkamp writes about his Trinitarian spirituality as follows:

He contemplated the Divinity in one nature and three persons, and basked in the love of the triune God. In the Trinity he saw the origin and the destiny of all that exists, and the ineffable bliss for which all men were created. His every thought and effort and undertaking converged on this truth: All must serve the triune God; all must be conquered for the Trinity; all must be done its name; all hearts must become Its abode; all men must come to know and love and adore the triune God. ${ }^{89}$

Janssen's conception of the Trinity above sees the Triune God in the perspective of Threeness and Oneness. This 'unityin-diversity' of the Trinity follows its contemporary notion as pointed out by Kisala that it should be understood in

$86 \quad$ Paulus Budi Kleden, Trinitarian Spirituality and Interculturality, in Intercultural Living, ed. S. Lazar and M. Ueffing, vol.1 (Delhi: ISPCK, 2015), 26.

87 Jürgen Ommerborn, "The Spirituality of Arnold Janssen for Lay Partners," Verbum SVD 58 no. 2-3 (2017): 211.

88 Herman Sandkamp, The Spirituality of our Founder (Chicago: 1948, New Layout published only in digital format: Rome: Generalate, 2010), 9.

89 Herman Sandkamp, The Spirituality of our Founder (Chicago: 1948, New Layout published only in digital format: Rome: Generalate, 2010), 9. their relationship with each other, and by extension with humanity. "The Father is Father in relation to the Son, the Son likewise is Son in relation to the Father, the Spirit is the boundless love of the Father and Son for each other flows over in relationship of love with the whole community." 90 He concludes that this relationship leads to communion.

Janssen's perception of the Trinitarian communion reflects the intercultural communication dimension of his spirituality. Referring to the Trinitarian communion of Love, the Church teaches that the "individuality of every divine person is fully respected and at the same time their unity is promoted." 91 The Trinitarian spirituality leads towards respecting the individuality, while relating to one another, of the Father, the Son and the Holy Spirit, and promoting the Oneness of the Trinity.

Such Trinitarian views can be seen in Janssen's spirituality as it was shown in his dealings with interculturality. $\mathrm{He}$ admonished every member of the Divine Word Missionaries to respect every other person whose cultural background is different. Inspired by the Trinitarian communion of Love, he put down a significant point as his legacy in the first General Chapter of the Society of Divine Word in 1885. In Janssen's words, it says: "It is strictly forbidden to criticize the nationality of a confrere or promote one's own at the expense of others or give a nickname to a confrere because of his nationality."92 Such respect, for Janssen, includes also the customs and cultures of other people.

\footnotetext{
90 Robert Kisala, "Theological Foundations of Interculturality," Verbum SVD 54 no.1 (2013): 27.

91 Paulus Budi Kleden, Trinitarian Spirituality and Interculturality, in Intercultural Living, 27.

92 Josef Alt, Journey in Faith: The Missionary Life of Arnold Janssen, 715.
} 
In a letter to Josef Freinademetz, the first missionary of the Divine Word Missionaries to China, he wrote: "Keep a critical eye on yourself, and particularly in consideration of Chinese customs, with which you should gradually become more acquainted and adjust to. And, for heaven's sake, try to learn Chinese well and thoroughly-not just enough to get along." 93 This shows that Janssen wished each member to respect the customs of the people with whom they lived and learn their language in order to be able to communicate well with them.

The other aspects of the Trinitarian spirituality lived by Janssen are rooted in community and reaching towards other people. One of the apparent qualities of the Trinity is the mutuality and equality between the three divine persons. This kind of relationship shows the communitarian aspect of the Trinity. All religious communities should model this communitarian dimension in which their members relate to one another equally, and they share, give and receive their common values in a modest way. And, as the Father, the Son and the Holy Spirit are unified in the circumference of Divine communication, ${ }^{94}$ the fullness of the Divine communion and communication between the three divine persons flows out to creation. Reaching out to humanity and all of creation, the Triune God shows solidarity with the suffering and neglected ones and is on the side of the poor and marginalized..$^{95}$

Being rooted in the Trinitarian spirituality, the task of the Divine Word Missionaries is to love actively and care for people just as God cares for them, not only externally

\footnotetext{
3 Josef Alt, Journey in Faith: The Missionary Life of Arnold Janssen, 14.

94 Carlo Maria Martini, Communicating Christ to the World, 21.

95 Paulus Budi Kleden, Trinitarian Spirituality and Interculturality, in Intercultural Living, 32.
}

toward other people, but also internally in a fraternal love with one another as a religious community. Janssen, thus, wrote the golden rule of Divine Word Missionaries as follows.

People are images of God, brothers and sisters of Christ, and temples of the Holy Spirit. Just as God cares for them out of the fulness of his love, endures their defects to reform them, so we, too, will love them actively. This will be our golden rule, whether we spread the faith or foster fraternal love. ${ }^{96}$

\section{INTERCULTURAL COMMUNICATION DIMENSION OF JANSSEN'S MISSION}

The whole narration of the life of Arnold Janssen was based on his unshakable commitment to realize the mission of God on earth. The mission flows from the Triune God, reaching out to humanity, and Janssen's particular way of doing mission is dialogue.

\section{Dialogue: A Way of Doing Mission}

Dialogue is another intercultural element in the life and mission of Janssen. In lieu of mission theology, dialogue is now seen as a way of doing mission. ${ }^{97}$ Bevans defines dialogue in mission as "a basic attitude, a kind of spirituality" that underlines every aspect of mission which involves "a spirit of openness." 98 The benefit of dialogue can only be acquired when those involved are allowed "to learn from and be challenged by those among they minister." 99 Through the lenses

\footnotetext{
96 Arnold Janssen, The Spirit and Task of Our society, in Peter McHugh, ed., Arnold Janssen, Yesterday and Today (Rome: 1998), 301.

97 Claudie Marie Barbour, Seeking Justice and Shalom in the City, quoted in Stephen Bevans, Prophetic Dialogue and Intercultural Mission in Intercultural Mission, ed. Lazar T. Stanislaus and Martin Ueffing, vol. 2 (Delhi: ISPCK, 2015), 205. See also in Roger Schroeder, "Interculturality and Prophetic Dialogue," Verbum SVD 54, no.1 (2013): 13-14.

98 Stephen Bevans, Prophetic Dialogue and Intercultural Mission in Intercultural Mission, ed. Lazar T. Stanislaus and Martin Ueffing, vol. 2 (Delhi: ISPCK, 2015), 206.

99 Stephen Bevans, Prophetic Dialogue and Intercultural Mission in Intercultural Mission, 206
} 
of dialogue, Janssen viewed the mission as "God's ongoing dialogue with humanity."100 In other words, the Triune God is always in dialogue with one another within the circle of Trinitarian communion and that same spirit of dialogue fills the encounter of the Triune God with all humanity.

The name of the Society founded by Arnold Janssen, the Divine Word or Logos, captures dialogue as a way of doing mission. The relationship between Logos and DiaLogos according to Joseph Ratzinger, Benedict XIV, reflects God's way of communication. ${ }^{101}$ In line with this concept, "Society of Divine Word (Logos)" should be a "society of dialogue, the society of DiaLogos", according to Eilers, which he claims to be the basis for dialogue and prophetic dialogue in mission. ${ }^{102}$

Janssen's intercultural character of dialogue can also be found in his writings in the Little Messenger. For Janssen, "mission was not a one-way street from Europe to the mission countries. Missionary work for overseas has or is supposed to have an effect on the people in the home or mission-sending countries, too." ${ }^{103}$ This concept leads us to apprehend that dialogue for Janssen is a prerequisite for communication to be effective which comprises the communication between the missionaries with the people to whom the missionary is sent, and with the people in the mission-sending countries as well. It

\footnotetext{
100 Michael Somers, Arnold Janssen, A Man of Dialogue in Precious is the Life Given for Mission: Reflection on the Centennial of the Death of Saints Arnold Janssen and Joseph Freinademetz (Italia: SVD-SSpS-SSpSAP Common Publication, GESP Italia, Città di Castello (PG), 2010), 52.

101 Joseph Ratzinger, "Einführung in das Christentum (München: Vorlesugen über das Apostolische Glaubenskenntnis) quoted in Franz-Josef Eilers, "Interculturality, Communication and the SVD," Dei Verbum SVD 54, no. 1 (2013): 56

102 Franz-Josef Eilers, "Interculturality, Communication and the SVD," Verbum SVD 54, no. 1 (2013): 56.

103 Jürgen Ommerborn, "The Spirituality of Arnold Janssen for Lay Partners," 261.
}

shows the dialogical dimension of Janssen's intercultural communication as found in the Little Messenger.

Janssen's dialogue with various people prior and subsequent to the establishment of the mission house indicates another intercultural communication dimension. The concept of dialogue as mission was grounded in his communication with bishop Raimondi, the perfect apostolic of Hong Kong. ${ }^{104}$ Their dialogue sought to inquire more information about the mission in what it called as a 'non-Christian' country, since Janssen would like it to be included in his mission magazine.

Janssen's concern about the foreign mission impressed bishop Raimondi and forced Janssen to initiate a mission school himself. This initial dialogue between Janssen and Raimondi served as a point of departure for other dialogues he made with various bishops and other people. From this perspective, it is true that dialogue for Janssen is "a way of being present in history; dialogue is not being passive; rather it is being courageous, restless, taking initiative."105 This courageous, restless and initiative spirit was at the core of his intercultural communication throughout his life and mission.

Janssen's competence in dialogue, moreover, was not only to harmonize the dispute and conflicts but also to bridge differences. He experienced several conflicts and disputes with the members of the mission house over the issues of the statutes and the purpose of the mission house, and he was faced with different personalities of

\footnotetext{
104 Josef Alt, Journey in Faith: The Missionary Life of Arnold Janssen, 44.

105 Michael Somers, Arnold Janssen, A Man of Dialogue in Precious is the Life Given for Mission: Reflection on the Centennial of the Death of Saints Arnold Janssen and Joseph Freinademetz , 53.
} 
the members. ${ }^{106}$ Recent studies have shown that in a multicultural group, many conflicts occur because of "differing cultural views and various values orientations." 107 This finding is helpful for understanding the conflicts and disputes which occurred between Janssen and his team. Within such a situation, the role of dialogue as was stressed earlier that not only brings hope and prevents a devastating breakdown of harmony but also offers the possibility of bridging diverse elements together to help build a better society. ${ }^{108}$

Janssen, as a founder, was grounded in the spirit of dialogue in his daily life. He managed to work through the disputes among the members of the mission house over the issue of statutes. They managed to resolve the issues with Janssen's ability to accommodate various dissenting opinions and make room for dialogue to occur between the members and himself. At the end of the day, several resolutions were made on the spiritual life, pastoral ministry, the purpose of the society and the patron of the house. ${ }^{109}$

After resolving such conflicts, he once described his inner feelings, as follows:

I have experienced periods of severe struggle and it seemed to me I would have to endure a crucifixion if I were to succeed. On top of that, I experienced a physical affliction and some adversity. But it seemed to me that to give up would

\footnotetext{
106 Josef Alt, Journey in Faith: The Missionary Life of Arnold Janssen, 99.

107 Xiaodong Dai and Gup-Ming Chen, Introduction, in Conflict Management and Intercultural Communication, the Art of Intercultural Harmony, ed. Xiaodong Dai and Gup-Ming Chen (London and New York: Routledge Taylor \& Francis Group, 2017), 1.

108 Benjamin J. Broom, Moving from Conflict to Harmony in Conflict Management and Intercultural Communication: The art of Intercultural Harmony, ed. Xiaodong Dai and Guo-Ming Chen (New York: Routledge, 2017), 23.

109 Josef Alt, Journey in Faith: The Missionary Life of Arnold Janssen, 124-126.
}

be contrary to God's will. So, I hung on, continued working, and I have no doubt that God wants the project and that he is the true agens who designs to use our poor hands for this purpose. ${ }^{110}$

\section{Anthropos Tradition: A Way of Doing Mission}

The founding of an 'Anthropos Tradition,'111 from the lenses of mission, is one of Arnold Janssen's milestones in intercultural communication. From the initial plan of the Anthropos publication, Janssen gave his full support to William Schmidt in his efforts to lead the publication in $1906 .{ }^{112}$ Eilers points out this connection by citing Koppers, saying: "All his life, Wilhelm Schmidt underlined in a special way the vivid interest and support of Arnold Janssen for his initiative as well as concern beyond European borders." 113

Janssen's trace on the Anthropos, and thus considered a heritage of the founder in the Society of Divine Word, was also acknowledged by Antonio Pernia, the Superior General of the SVD (2000-2012). Pernia, who coined the term 'Anthropos Tradition', elucidates that "this is the heritage that we have received from those most identified with the charism of our Society a heritage articulated by Schmidt,

\footnotetext{
110 Josef Alt, Journey in Faith: The Missionary Life of Arnold Janssen, 52.

111 The Anthropos tradition refers to two factors: a scientific journal known as Anthropos (1906) and the institute known as Anthropos Institute (1931) both of which were founded by Wilhelm Schmidt. The purpose of the Anthropos is to publish reports and studies of missionaries on the peoples and cultures where they worked.

112 Fritz Bornemann, Arnold Janssen Founder of Three Missionary Congregations 1837-1909: A Biography (Manila: Arnoldus Press, 1975), 359. See also Jaochim G. Piepke, "The Anthropos Institute. The task of Basic Research in Mission," Verbum SVD 46, no. 2 (2005): 189. See Ernest Brandewie, When Giants Walked the Earth: The Life and Times of Wilhelm Schmid SVD (Sankt Augustin: Anthropos-Institut \&: University Press Fribourg, 1990), 51.

113 Franz-Josef Eilers, "Interculturality, Communication and the SVD", 52.
} 
but originating from Janssen himself..."114 He stresses that the Anthropos Tradition is a way of doing mission. It appreciates people's culture and perceives such appreciation as a necessary precondition in a genuine evangelization.

In the perspective of mission, moreover, the "message of the gospel is not simply parachuted from outside, but enters into dialogue with the culture of the people."115 The main character of Anthropos according to Schmidt deals with "people and their culture, with people and the variety of their cultures and how they relate to their own and other cultures." 116 In fact, the founder's intention of the Anthropos attempted to assist the missionaries "to understand and foster what might today be called multicultural encounter" and simultaneously would help the missionary work of the Divine Word Missionaries. ${ }^{117}$ As a way of doing mission, the Anthropos tradition has called the missionary not just "to change people but to be changed himself or the evangelizers not only to evangelize but allows himself or herself to be evangelized." 118

The traditional mission however views mission as a way of crossing into, or entering, other cultures. To put it in a context, the missionaries in the past "crossed" cultural differences to bring the

\footnotetext{
114 Antonio Pernia, "Expectation of the Generalate of the Anthropos Institute," quoted in Ennio Mantovani, "Anthropos Tradition in the SVD Yesterday and Today," Verbum SVD 46, no. 2 (2005): 207.

115 Antonio Pernia, "Expectation of the Generalate of the Anthropos Institute," quoted in Ennio Mantovani, "Anthropos Tradition in the SVD Yesterday and Today", 207.

116 Othmar Gächter, "The Encounter Between Religions and Cultures; 100 Years of Anthropos-International Review of Anthropology and Linguistics," Verbum SVD 46, no. 2 (2005): 193.

117 Othmar Gächter, "The Encounter Between Religions and Cultures; 100 Years of Anthropos-International Review of Anthropology and Linguistics", 194.

118 Antonio Pernia, "Expectation of the Generalate of the Anthropos Institute," Verbum SVD 45, no.1 (2004): 19-37 quoted in Ennio Mantovani, Anthropos Tradition, 208.
}

"faith". ${ }^{119}$ This approach is done through intercultural communication. It is a kind of communication that "crosses borders into other cultures."

The new approach of mission theology, however, has shifted from the cross-cultural perspective. The Second Vatican council, Ad Gentes, leads the new perspective by defining mission as presence and saying that "the Church makes herself fully present to all individuals and peoples in order to lead them to faith, freedom and peace of Christ..." ${ }^{120}$ It means that the proclamation of the Word of God cannot be separated from the form in which it is communicated (AG no.5). It has to be made present to the people in a given context through the means and method of communication that are relevant to their lives and comprehensible.

The Anthropos Tradition that has been brought by Janssen in the early twentieth century is in line with the concept of intercultural communication within the lenses of mission theology. With this new perspective of mission as presence, the church's mission in an intercultural society should be undertaken in a form of dialogue. Dialogue in this sense refers to 'any form of mutual communication, in which both sides listen and talk, give and take, learn and share."121 This principle is indeed the concern of intercultural communication which is characterized by its participatory dimension. In this approach, each person "shares and becomes one with the other in the attempt to mutually understand and cooperate." ${ }^{122}$

\footnotetext{
119 Franz-Josef Eilers, "Interculturality, Communication and the SVD", 406.

120 Franz-Josef Eilers, "Interculturality, Communication and the SVD", 406.

121 Franz-Josef Eilers, "Interculturality, Communication and the SVD", 406.

122 Franz-Josef Eilers, "Interculturality, Communication and the
} 
Drawing from such participatory character, the intercultural communication approach follows the form of dialogue that Anthropos has proposed and practiced. The main content of the publication includes reports and studies of the missionaries about the peoples among whom they worked, and their cultures. ${ }^{123}$ Not only that, Schmidt sent several teams of field researchers such as Schebesta to live and work among the Semang and Senoi people of Malacca and to the Kubu people in Sumatera, Indonesia. ${ }^{124}$ Schmidt hoped for the researchers to experience direct interaction with the people and observe their cultures first hand. In such a process, a mutual dialogue takes place. Along the same line, Janssen in his life and mission as the founder encouraged all of his missionaries to collect data in the fields of ethnology, anthropology and related subjects about the culture of the people, as they experience the people's way of life while living and working in their midst.

The Anthropos Tradition still exists today. Standing upon the Founder's personal concerns about people and their various cultures, the Anthropos Tradition continues to be carried out by all members of the Divine Word Missionaries in their concerns for all people with their varied customs and cultural realities.

\section{CONCLUSION}

This research started with the question: What is the intercultural communication dimension of the life and mission of Arnold Janssen? Janssen's intercultural communication dimension was primarily cultivated at his home through his family's culture of prayer and culture of peace. From there, he inherited the Trinitarian Spirituality and passed it down to the Divine Word Missionaries (SVD). This spiritual and intercultural dimension characterizes his personality, legacies and mission. Janssen's journey towards the establishment of the mission house was inseparable from his involvement in communication. Communication is, therefore, not only the cornerstone of the foundation of the SVD but also a point of departure of his engagement with what is nowadays called intercultural communication.

The life of the SVD finds its roots in the Founder's spirit of intercultural communication. In fact, this feature is not only seen through the multiculturality of its members but also the missionary works which the SVD has established in more than eighty countries around the world. In light of the Founder's spirit, the seventeenth General Chapter of the SVD (2012) recommends a particular way of doing mission through prophetic dialogue which favors intercultural communication and is relevant to today's reality. Moreover, the publication of the Anthropos contributes to this spirit. The realization of the founder's intercultural communication is found in the formation of the SVD.
SVD", 406.

123 Franz-Josef Eilers, "Interculturality, Communication and the SVD", 51.

124 Wilhelm Schmidt, Die Forschungsexpedition Von P. P. Schebesta, SVD., in 1924/1925 bei den Semang-Pygmäen und den Senoi-Pygmoiden auf der Halbinsel Malakka (British Malaya. Antrhropos 20:71 8-739 quoted in Joachim G. Piepke, "The Anthropos Institute, The Task of Basic Research in Mission," Verbum SVD 46:2 (2005), 187. 


\section{BIBLIOGRAPHY}

\section{A. Church Documents}

Second Vatican Council. Ad Gentes. Decree on the Mission Activity of the Church, 1965.

Second Vatican Council. Gaudium et Spes (Pastoral Constitution on the Church in Modern World), 1965.

\section{B. Books}

Alt, Josef. Journey in Faith. The Missionary Life of Arnold Janssen. Romae: Aud Collegium Verbi Divini. 2002.

Bornemann, Fritz. Arnold Janssen Founder of Three Missionary Congregations 18371909, A Biography. Manila: Arnoldus Press Manila, 1975.

Collier, M. J. et.al. (Eds.) Transforming Communication About Culture. Thousand Oaks, Ca: Sage, 2002.

Dai, Xiaodong and Ming Chen, Guo, Eds. Conflict Management and Intercultural Communication. The art of Intercultural Communication. London and New York: Routledge Taylor \& Francis Group, 2017.

Eilers, Franz-Josef, SVD. Communicating Between Cultures. An Introduction to Intercultural Communication. Fourth Updated Edition. Manila: LOGOS (Divine Word) Publications, 2012

Eilers, Franz-Josef, SVD. Communicating in Community. An Introduction to Social Communication. Fourth Updated Edition. Manila: LOGOS (Divine Word) Publications, 2009

Eilers, Franz-Josef, SVD. Communicating in Ministry and Mission: An Introduction to Pastoral and Evangelizing Communication, $4^{\text {th }}$ updated edition. Manila: Logos (Divine Word) Publications, Inc, 2018.

Eilers, Franz-Josef and Heinz Helf, Arnold Janssen, 1937-1909: A Pictorial Biography, $2^{\text {nd }}$ Edition. Manila: Philippine Edition Divine Word Publication,1987.

Estioko, Leonardo R. Witness to the Word. Manila: Logos Publication, 2005.
Hall, Edward T. The Silent Language. Garden City, New York: Doubleday \& Company, Inc, 1959.

Hesselgrave, David J. Communicating Christ Cross-Culturally. An Introduction to Missionary Communication. 2nd Edition. Grand Rapids, Michigan: Zondervan Publishing House, 1991.

Holliday, Adrian, Kullman, John and Hyde Martin. Intercultural Communication, An advanced Resource book for Students. London. Third Edition. and New York: Routledge, Taylor \& Francis Group, 2017.

Klyukanov, Igor E. Principles of Intercultural Communication. Boston: Pearson Education, Inc, 2005.

Luzbetak, Louis J. The Church and Cultures: An Applied Anthropology for the Religious Worker. Techny, Illinois: Divine Word Publications, 1970.

Maletzke, Gerhard. Intercultural and International Communication, in International and Intercultural Communication, ed. Fischer, H.D./ Merill, John C, Second Edition. New York, 409-419.

Martini, Carlo Maria. Communicating Christ to the World. Diliman, Quezon City: Claretian Publications, 1996.

Milton, J. Bennett J. Intercultural Communication: A Current Perspective, in Basic concepts of intercultural communication: Selected readings, ed. Milton J. Bennett. Yarmouth, ME: Intercultural Press, 1998.

Neher William W and Paul J. Sandin. Communicating Ethically; Character, Duties, Consequences and Relationship. New York and London: Routledge, Taylor \& Francis Group, 2017.

Neuliep, James W. Intercultural Communication. A Contextual Approach. Thousand Oaks, California: Sage Publication, Inc. 2006.

Rehbein, Franziska Carolina. Gripped by The Mystery, Arnold Janssen - Man of Prayer. Steyler Verlag: Arnold Janssen Spirituality Center (AJSC), 2004. 
Sandkamp, Herman. The Spirituality of our Founder. Rome: SVD Generalate, 2010. Samovar, Larry A. Porter, Richard E, Mcdaniel, Edwin R. Intercultural Communication, A Reader. Boston: Wadsworth Cengage Learning, 2009.

Schroder. Roger P. What is the Mission of the Church? A Guide for Catholics. Maryknoll, NY: Orbits Books, 2008.

Somers, Michael. Arnold Janssen, A Man of Dialogue in Precious is the Life Given for Mission: Reflection on the Centennial of the Death of Saints Arnold Janssen and Joseph Freinademetz. Italia: SVD-SSpS-SSpSAP Common Publication, GESP Italia, Città di Castello (PG), 2010.

Stanislaus, Lazar T. and Ueffing, Martin (Eds.). Intercultural Living (Vol.1). 1st Ed. Dr Ashish Amos of the Indian Society for Promoting Christian Knowledge (ISPCK) and Steyler Missionswissenschaftliches Institut, $\backslash 2015$.

Stanislaus, Lazar T. and Ueffing, Martin. Intercultural Mission (Vol.2). 1st Ed. Dr Ashish Amos of the Indian Society for Promoting Christian Knowledge (ISPCK) and Steyler Missionswissenschaftliches Institut, 2015.

\section{Articles}

Gachter, Othmar, SVD. "The Encounter between Religions and Cultures. 100 Years of Anthropos-International Review of Anthropology and Linguistics." Verbum SVD 26, no. 2 (2005): 193-205.

Kisala, Robert, SVD. "From Every Nation, People, and Language." Verbum SVD 53, no. 1 (2012): 31-40.

Mantovani, Ennio, SVD. "Antrophos Tradition in the SVD Yesterday and Today." Verbum SVD 46. No. 2 (2005): 207-223.

Ommerborn, Jürgen, SVD. “Arnold Janssen's Understanding of Mission in the Context of His Time. Verbum SVD 49 no. 3 (2008): 241-266.
Ommerborn, Jürgen, SVD, “Arnold Janssen's Understanding of Mission in the Context of His Time, Part II." Verbum SVD 49, no. 4 (2008): 369-393.

Ommerborn, Jürgen, SVD, "The SPirituality of Arnold Janssen For Lay Partner. Verbum SVD 58, no. 2-3 (2017): 210-221.

Pernia, Antonio. "Missio Inter Gentes." Arnoldus Nota (2009):

Piepke, Joackim G, SVD. "The Anthropos Institute. The Task of basic Research in Mission." Verbum SVD 46, no. 2 (2005): 179192.

Poruthur, Anthony, SVD. “Arnold Janssen's Passion for Science." Verbum SVD 46, no. 3 (2005): 353-360.

Poruthur, Anthony, SVD. "Journeying with SVD Internationality vis-à-vis Multi-mutuality. Verbum SVD 54, no. 2 (2013): 240-250.

\section{Electronic Sources}

Aba, Diler. "Towards an Intercultural Communication Competence Tool for Academic Mobility Purposes." Retrieved January 28, 2019 from https://www.immi.se/intercultural/

Matthew Bunson, German Catholics Under the Iron Fist: Bismarck and the Kulturkampf derived on October 26, 2019 from https:// www.catholicculture.org/culture/library/view. cfm?recnum $=8670$

Divine Word Missionaries (SVD): http://www. svdcuria.org

Secretariat for Non-Christians, "The Attitude of the Church Towards Followers of Other Religions: Reflections and Orientations on Dialogue and Mission," Bulletin. Secretariatus pro non Christianis 56:13, 1984/2, Paragraph 29.

SVD History and Tradition: http://www.svdcuria. org/public/histtrad/index.htm 